\title{
THOUGHT IN THE SERVICE OF INTUITION: HEIDEGGER'S APPROPRIATION OF KANT'S SYNTHETIC A PRIORI IN DIE FRAGE NACH DEM DING *
}

\author{
Cristina Crichton** \\ https://orcid.org/0000-0002-5345-4335 \\ cristina.crichton@uai.cl
}

\begin{abstract}
RESUMO É consenso geral que o pensar de Kant influenciou fortemente o pensar de Heidegger. Porém, há ainda muito trabalho a fazer para se conseguir apreciar essa influência plenamente. Um tema crucial para conseguir expor a relação entre esses dois autores é o rol que ambos dão ao transcendental. Neste artigo, vou mostrar que o tratamento que Kant faz da intuição é o foco da interpretação que Heidegger oferece acerca de Kant em sua obra Die Frage nach dem Ding, dado que Heidegger interpreta o jeito como Kant trabalha a intuição como uma delimitação da tendência matemática moderna a determinálo tudo pelo só uso da razão pura. Argumento que essa interpretação está na base da apropriação que Heidegger faz do sintético a priori kantiano nesta obra, cujo fim é tirar essa noção fora da esfera dos objetos da ciência físicomatemática e posicioná-la no reino da experiência cotidiana. Sustento que Heidegger pensa que isto só pode ser alcançado ao eliminar a necessidade e a universalidade (certeza epistêmica) do a priori kantiano. Finalmente, mostro que a apropriação que Heidegger faz do sintético a priori kantiano vai junto e ilumina sua compreensão da transcendência como o das Zwischen, 'o entre nós e as coisas'.
\end{abstract}

** Universidad Adolfo Ibáñez. Santiago, Chile. 
Palavras-chave Heidegger, Kant, sintético a priori, experiência cotidiana, transcendência.

ABSTRACT There is general agreement that Kant's thought strongly influenced Heidegger's. Nevertheless, there is still much work to be done in order to fully appreciate this influence. A central theme to disclose the relation between these authors is the role they give to the transcendental. In this paper I show that Kant's account of intuition is the focus of Heidegger's interpretation of Kant in his Die Frage nach dem Ding, since Heidegger interprets Kant's treatment of intuition as a delimiting of the modern mathematical tendency to determine everything out of pure reason alone. I argue that this interpretation is at the basis of Heidegger's appropriation of Kant's synthetic a priori in this work, the aim of which is to take this notion away from the sphere of the objects of mathematical physical science, and place it in the realm of everyday experience. I claim that Heidegger thinks that this move can only be accomplished by removing universality and necessity (epistemic certainty) from Kant's a priori. Finally, I show that Heidegger's appropriation of Kant's synthetic a priori goes together with and illuminates his understanding of transcendence as das Zwischen, 'the between us and things'.

Keywords Heidegger, Kant, synthetic a priori, everyday experience, transcendence.

\section{Introduction}

The influence of Kant's transcendental idealism on Heidegger's thoughtespecially on his early works and Being and Time ${ }^{1}$ (1928) - is undeniable. Thus, the relationship between both thinkers has caught the attention of a number of Heidegger scholars. Nevertheless, as Jeff Malpas and Steve Crowell suggest, more attention needs to be given to the role of the transcendental in Heidegger's thinking, as well as Heidegger's stance toward the tradition of transcendental thought as such $(2007$, p. 1).

Though there are several ways of saying what is it that fascinated Heidegger about Kant, there is general agreement that Kant's investigation into the conditions of the possibility of experience is at the heart of it. Heidegger's 
words in the Phenomenological Interpretation of Kant's Critique of Pure Reason $^{2}(1927 / 8)$ are illuminating in this respect:

Briefly the problem is the following: How can understanding open up real principles about the possibility of things, i.e., how can the subject have in advance an understanding of the ontological constitution of the being of a being? Kant sees this correlation, one which we formulate in a more basic and radical manner by saying: Beings are in no way accessible without an antecedent understanding of being. This is to say that beings, which encounter us, must already be understood in advance in their ontological constitution. This understanding of the being of beings, this synthetic $a$ priori knowledge, is crucial for every experience of beings. This is the only possible meaning of Kant's thesis, which is frequently misunderstood and which is called his Copernican revolution (Heidegger, 1997a, p. 38/55). ${ }^{3}$

As this quote shows, Heidegger thinks that the transcendental question about the conditions of the possibility of experience must be understood in ontological terms, and the same goes for the synthetic a priori. It is not surprising, then, that the relation between Kant's critical project and Heidegger's fundamental ontology has been widely studied and debated. William Blattner, for example, argues that Heidegger rejects Kant's transcendental idealism because he follows out the implications of characterizing Kant's conception of objectivity as an understanding of being (2004, p. 326). For his part, Sacha Golob shows that Heidegger understands the Critique of Pure Reason ${ }^{4}$ as an extended, selfdirected transcendental argument - which implies that Heidegger's use of 'transcendental' cannot be understood in terms of the familiar Kantian model of a transcendental argument. He thinks that the reason this has not been recognized previously is that Heidegger equates the synthetic a priori with the ontological (2012, p. 9).

The above-mentioned analyses and, in general, most of the work devoted to the study of Heidegger's understanding of Kant's thought, mainly concentrates on Heidegger's comments about this author in early works such as $B T$ and The Basic Problems of Phenomenology ${ }^{5}$ (1927) and in his first two works on Kant: PIK and Kant and the Problem of Metaphysics ${ }^{6}$ (1929). There are very few analyses that focus on the lecture course of the winter semester of 1935/1936

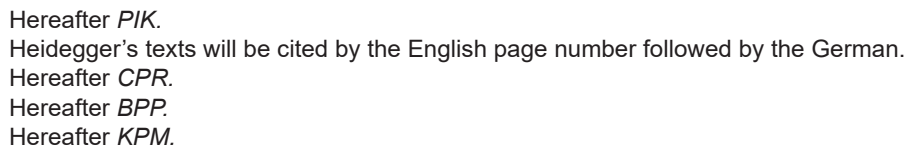


entitled What is a Thing ? $^{7}$ As the original German subtitle reads, this lecture course offers a study of Kant's doctrine of the transcendental principles.

According to Trish Glazebrook, Heidegger reads Kant in $W T$ 'with an openness not earlier evident. Rather than attempt to adapt the Critique into the project and terminology of Being and Time [which she thinks Heidegger does in $K P M]$, this text seeks to explore what Kant's thought makes possible in the history of metaphysics. Kant opens up a dimension between thinker and thing in which to raise the question of Being' (2000, p. 41). In similar vein, David Carr thinks that $W T$ and Kant's Thesis About Being ${ }^{8}$ (1961), compared with $B T, B P P, P I K$ and $K P M$, 'derive from a very different perspective not only on Kant but on the history of modern philosophy generally' (p. 29). Daniel Dahlstrom, who has produced significant work on 'Heidegger's Kantian turn' in Heidegger's lectures and other writings shortly before and after the composition of the final draft of $B T,{ }^{9}$ recognizes that in Contributions to Philosophy (1930) Heidegger deems his project of fundamental ontology as "transitional" and its transcendental path "provisional" (2007, p. 63). This clearly calls into question the continuity between Heidegger's interpretations of Kant's thought before and after $1930 .{ }^{10}$ For W.B. Barton, the characteristic of Heidegger's interpretation of Kant in $W T$ is that Kant's treatment of intuition takes centre stage. He suggests that this is a major shift from Heidegger's interpretation of Kant in KPM, where the focus was placed on transcendental imagination (1973, p. 16).

I am sympathetic to the view that there is an important shift in Heidegger's interpretation of Kant in WT. Indeed, Heidegger indirectly suggests in this work that the B edition of Kant's CPR is more philosophically insightful than the A edition - a view that he explicitly affirms almost three decades later in $K T B$ (1998, pp. 345, 347/455, 458) - whereas in KPM Heidegger thinks the opposite is the case. ${ }^{11}$ Even though it is not my intention here to offer an analysis of the reason for these changes, I bring them to the reader's attention as an indication that an analysis of Heidegger's interpretation of Kant in WT must offer new insights into the relationship between Heidegger's thought and transcendental philosophy. ${ }^{12}$ It is thus beyond the scope of this paper to compare Heidegger's

7 Hereafter WT. The original German title for WT is Die Frage nach dem Ding. Zu Kants Lehre von den transzendentalen Grundsätzen. In this paper I will use the first English translation of this work (1967), but I will also refer to the second English translation (2018) when convenient.

8 Hereafter KTB.

9 See for example Dahlstrom (1991).

10 For an analysis of the vestiges of the transcendental turn in Heidegger's later thinking, see Dahlstrom (2005).

11 I will refer to the difference between Heidegger's preferences for the editions of the CPR in WT and KPM in footnote 17.

12 David Carr offers an interesting analysis of Heidegger and Kant on transcendence that is exclusively based on the first two books on Kant and, at the same time, makes a case for Heidegger's preference for the A 
early interpretations of Kant's thought with that in $W T$, but to offer an analysis of this later interpretation which can serve as a basis for future research into the continuities and discontinuities in Heidegger's interpretation of Kant.

In this paper I will show that the focus of Heidegger's interpretation of Kant's thought in WT is sensible intuition, which is crucial for his appropriation of Kant's synthetic a priori. This will cast new light on Heidegger's understanding of transcendence in this work, thus providing new elements to study the relationship between Heidegger and transcendental philosophy in this phase of his thought.

I will begin by arguing that Heidegger's interpretation of Kant's treatment of intuition as a delimitation of the modern mathematical tendency to determine everything out of pure reason alone, allows us to place Kant's account of intuition at the centre of Heidegger's interpretation of Kant in WT. I will then show that Heidegger never uses the expression 'synthetic a priori' in relation to Galileo or Newton in $W T$, but the expression 'the mathematical' since he does not want to ascribe necessity and universality (epistemic certainty) to Kant's a priori. I will proceed by suggesting that Heidegger draws attention to the distinction between Kant and Newton with respect to the epistemic certainty in their conceptions of the a priori in order to show that even though Kant does not attend to that which encounters us prior to an objectification into an object of scientific experience, his focus on intuition betrays the possibility of doing it. Finally, I will show that Heidegger's appropriation of Kant's synthetic a priori in $W T$ is fundamentally linked to his understanding of transcendence as 'the between' in this same work. I conclude with a few remarks on the importance of reading Heidegger's interpretation of Kant's thought in WT from the perspective of the possibilities that it opens up within the history of metaphysics.

edition of the CPR in both KPM and PIK. Carr pays attention to Heidegger's criticism of Kant's use of the term 'deduction' in 'The Deduction of the Pure Concepts of Understanding'. He argues that this criticism shows that Kant remains within the framework that 'set the terms of the debate about knowledge carried out by Kant predecessors, beginning with Descartes' (2007, p. 31). Insofar as Heidegger thinks that the problem dealt with in the deduction is transcendence, and thus the transcendental character of the subject, Descartes' isolated subject cannot have such a decisive role. Nevertheless, at least in the A edition Kant deals with the subject, whereas in the B edition he supresses the subjective side of the deduction, which is why Heidegger prefers the former: Kant 'departed from his original insight, limited as he was by what he saw as the options open to him' (p. 33). In short, Kant did not have the philosophical resources to realise that what was needed was a purely phenomenological interpretation of human existence (Dasein) as knowing. 


\section{Heidegger's interpretation of Kant's thought as an attempt to delimit the mathematical in $W T$}

The background of Heidegger's interpretation of Kant's thought in WT is the opposition between modern scientific thinking and everyday thinking (1967, pp. 1-54/1-53). He wants to show that scientific thinking is not the only way of thinking and therefore of disclosing reality; it is only one way of thinking that, nonetheless, has taken over the whole of our being. Heidegger's stance toward this type of thinking is not sympathetic: ' ... what most holds us captive (gefangen) and makes us unfree (unfrei) in the experience and determination of the things. This is modern natural science, insofar as it has become a universal way of thinking along certain basic lines' (p. 51/49).

In line with this opposition, Heidegger employs the term 'experience' in two senses: scientific, and everyday experience of things (Alltägliche und wissenschaftliche Dingerfahrung) (pp. 11-14/10-14). In reference to everyday experience, he uses expressions such as 'the things that surround us' (pp. $128,129 / 131$ ) or what is 'intuitively given' (pp. 139, 141/141-142, 143). With respect to scientific experience, Heidegger suggests that it is the result of a mathematical project (Entwurf). Even though he admits that mathematical thinking has its first expression in Greek philosophy, Heidegger thinks that it acquires a specific characteristic in modernity: mathematical thinking is guided by representations against the evidence of the ordinary experience of things. He argues that these are counterintuitive representations, seeing in Newton a clear representative of this type of thinking (pp. 66-95/66-95). To support this view, Heidegger offers an analysis of Newton's first law of motion that he renders thus: 'Every body continues in its state of rest, or uniform motion in a straight line, unless it is compelled to change that state by force impressed upon it' (p. 78/79). Heidegger thinks that the sense in which modern mathematical thinking becomes decisive in this law is expressed by the fact that it speaks of a thing (a body) that does not exist. Hence, he thinks that this law demands a fundamental representation of things that contradicts our ordinary experience of things (p. 89/89-90). As I have argued elsewhere, Heidegger considers that insofar as this law applies to something that does not exist (a body not impressed by any external force), there is no way in which it can be derived from our ordinary experience, or, in other words, from our sensible intuitions (2019, p. 180). Nevertheless, this law is projected upon 'reality', and thus it discloses reality in a certain way, i.e., scientifically. This means that the modern mathematical way of thinking, going against the evidence of ordinary experience, is actually able to determine experience. How is this possible? As I have suggested elsewhere, Glazebrook's account of the violence that takes place 
in the modern mathematical projection of nature, and the reduction of reality that this entails, is a sound answer to this question (p. 183). ${ }^{13}$ Still, Heidegger takes a step further and suggests that the modern mathematical way of thinking has a tendency to extend its dominion beyond the scientific sphere. Thus, it colonizes metaphysics, because from there it can extend its dominion to beings as a whole. Heidegger thinks that when this happens, metaphysics becomes rational metaphysics, the characteristic of which is to project the determinations of the being of what is out of pure reason alone (1967, p. 118/119), without the help of a relation to something previously given before one (p. 108/108-109).

With respect to our everyday experience, Heidegger thinks that 'there is not at first, nor later on, any valid reason to doubt our everyday experiences' ( $p$. 11/11). But he is also clear in saying that it is not enough simply to say that there is truth and certainty in everyday experience: 'Precisely if everyday experience carries in itself a truth, and a superior [ausgezeichnete] truth at that, this truth must be founded, i.e., its foundation must be laid, admitted, and accepted' (p. 12/12). ${ }^{14}$ To picture this, Heidegger compares our everyday experience of the sun, the diameter of which is at most half a meter to one meter wide and wanders over the earth, with the sun known by the astrophysicist, which contradicts these two descriptions of it (pp. 12-13/12-13). The question, thus, is: which is the truth in our everyday experience of the sun that is superior to the truth of the sun known by the astrophysicist?

I suggest that in WT Heidegger reads Kant as a thinker who can help in the task of laying the foundation for the truth involved in everyday experience, insofar as his thought brings to light philosophical elements that can put limits to the dominating tendency of the modern mathematical way of thinking. Nevertheless, Heidegger thinks that this is so only if these elements undergo a new philosophical appropriation. Without this appropriation, Kant's thought remains subjected to the modern dominance of the mathematical. I will thus divide this section in two parts. The first will address what Heidegger takes to be Kant's possibility of delimiting the modern mathematical way of thinking, while the second will address why Heidegger considers Kant to be subjected to this way of thinking.

13 For an analysis of Heidegger's understanding of the mathematical in relation to these two senses of experience and their corresponding types of thinking (representation) in WT, see Crichton (2019).

14 The second English translation of Die Frage nach dem Ding translates the German term ausgezeichnete as 'exceptional' (Heidegger, 2018, p. 8/12). Though this is certainly a correct translation, I think the term 'superior' captures in a better way what is at stake in the opposition between the truth involved in scientific and everyday experience. As it will become clear in what follows, this is a crucial issue in my reading of Heidegger's interpretation of Kant in WT. 
In what follows, the expression 'the mathematical' will refer to the modern mathematical way of thinking, that is, a way of thinking guided by representations against the evidence of our everyday experience of things, or, in other words, guided by representations that are the result of pure reason alone.

\section{i. Kant's focus on intuition as the decisive blow against the mathematical}

The first and decisive indication for understanding Heidegger's view of Kant's philosophy as a new delimitation of the mathematical follows from Kant's definition of the essence of knowledge that Heidegger quotes: 'In whatever manner and by whatever means a mode of knowledge may relate to objects, intuition is that through which it is in immediate relation to them, and to which all thoughts as a means is directed. But intuition takes place only insofar as the object is given to us (der Gegenstand gegeben wird). This again is only possible, to man at least, insofar as the mind (Gemüt) is affected in a certain way' (Kant, cited in Heidegger, 1967, p. 134/137). ${ }^{15}$ This essential definition of knowledge, says Heidegger, is 'the first and completely decisive blow against rational metaphysics' (der erste und zugleich alles entscheidende Gegenschlag gegen die rationale Metaphysik). With this definition of knowledge, he thinks 'Kant moved into a new fundamental position of man in the midst of what is, or more precisely he lifted a position, which, at bottom, had always existed, into explicit metaphysical knowledge and laid a basis for it' (p. 135/137-138). Heidegger insists that the novelty of this definition lies in Kant's focus on intuition, from which it follows that 'thought belongs to intuition and in such a way that it stands in the service of intuition' (p. 135/138). Therefore, Heidegger thinks that human knowledge is a uniquely constructed unity of intuition and thought, but a unity in which intuition has a priority over thought.

Why then, Heidegger asks, does the doctrine of intuition have around 40 pages whereas the doctrine of thought has more than 650 pages? (p. 144/147). For Heidegger, the doctrine of thought is so extensive because 'judgement must be defined anew' (p. 146/149):

The priority of logic in the Critique of Pure Reason has its ground solely in the nonpriority of the object of logic, i.e., in placing thought into the service of intuition [in der Dienststellung des Denkens gegenüber der Anschauung] ...The modest extent of the aesthetic - as the initial separate doctrine of intuition - is only an outward appearance. Since the aesthetic is now decisive, i.e., everywhere plays an authoritative part; therefore it makes so much work for logic. For this reason logic must turn so extensive (Heidegger, 1967, pp. 146-147/149-150). 
Heidegger thinks that the neo-Kantian interpretation of the $C P R$ leads to a devaluation of intuition as the basic component of human knowledge, and that the interpretation of the Marburg school went so far as to eliminate intuition altogether from the $C P R$ as a foreign body (p. 145/148). ${ }^{16}$ Thinking that the question about knowledge in Kant is nothing more than the question about judgment is, for Heidegger, a prejudice that has prevented scholars from penetrating into the centre of Kant's work (p. 145/148). ${ }^{17}$

Therefore, it is Kant's focus on sensible intuition what Heidegger takes to be central to delimiting the mathematical tendency to determine everything out of pure reason alone, insofar as it entails 'the given' of something that affects us. Nevertheless, Heidegger is explicit in saying that despite of this, Kant remains within the mathematical way of thinking.

16 Heidegger's view of the fundamental role of the aesthetic, and thus of intuition, aligns him with a non-conceptualist reading of Kant's work. As Colin McLear points out, '[o]ne of the central topics of debate in contemporary Kant scholarship has been whether Kant endorses a position concerning the nature of sensory experience called "conceptualism." As a first approximation, conceptualism about experience is the claim that the capacity for conscious sensory experience of the objective world depends, at least in part, on the repertoire of concepts possessed by the experiencing subject, insofar as they are exercised in acts of synthesis by the cognitive faculty which Kant terms the "understanding" [Verstand]' (2014, p. 769). As I have already suggested, in WT Heidegger makes the distinction between two types of experience: scientific determined experience and everyday experience. As I also already pointed out, he is looking for the philosophical foundation of the latter. As will become clear in the following sections of this paper, Heidegger thinks that Kant's focus on intuition can work as an access to everyday experience, and he suggests that this move can only by accomplished by removing universality and necessity from Kant's a priori. In this way, Heidegger weakens the role of understanding in our everyday experience of the world. This being so, I think that the conceptualist/non-conceptualist debate regarding the role of intuition and concepts in our experience of the world addresses the crucial issue for Heidegger's analysis of Kant's focus on intuition in WT. Although there are discrepancies among the different representatives of non-conceptualist readings, they all agree in reducing the importance of the role of concepts in favour of increasing the role of intuition. What motivates non-conceptualist readings is the view that Kant thinks that - to varying degrees depending on the type of non-conceptualist reading in question - intuitions are sufficient for the production of objectively valid cognitions over and above any conceptual contents (whether empirical or non-empirical) that might be associated with those intuitions. Thereby, a central idea in which non-conceptualism finds support - among others - is that sensibility is the faculty 'through which objects are given to us', an idea which Kant states in various sections throughout the CPR. As Lucy Allais points out, Kant claims that intuitions are singular and immediate representations which give us objects $(2015, \mathrm{p}$. 146). It is not clear what Kant means by saying that intuitions give us objects and, consequently, this issue has been a central point in the discussion between conceptualist and non-conceptualist readings of Kant's work. In Allais' treatment of this issue, the singularity of intuitions should be understood as their representing perceptual particulars and the immediacy of intuitions as their giving us acquaintance with or presenting the particulars they represent. For her, this is what Kant means when he says that intuitions give us objects: intuitions give us acquaintance with objects (pp. 147, 163). In light of this, it seems reasonable to think that Heidegger's view of the decisive role of intuition in Kant's CPR could entail conceiving intuitions in this way. Does Heidegger think that Kantian intuitions present us with objects without the need of conceptual mediation? I will address this issue in footnote 19.

17 Heidegger notes here that the extensive treatment of one component of knowledge, namely thought, is stressed even more in the B edition of the CPR (1967, p. 146/149). Following his argument, this means that in the B edition Kant makes an even greater effort to rethink thought and, thus, that the B edition is an even more faithful attempt to accomplish the 'novelty' of his thought than the A edition. This is an interesting point since in his KPM Heidegger sees the priority of understanding of the B edition as a 'shrinking back' from the insight achieved in the A edition about the synthesis of intuition and thought in imagination, an insight that shows how understanding is inherently finite through its inseparability from possible experience, its bond to intuition (1997b, pp. 112-116/160-165). 
ii. Kant's double usage of the term Gegenstand as an indication of his permanence within the mathematical

Following the twofold determination of human knowledge, that is, intuition and thought, Heidegger offers an account of the twofold determination of the object $^{18}$ in Kant's thought. Heidegger thinks that this twofold determination is seen in the German term Gegenstand: 'What we are supposed to be able to know must encounter us from somewhere, come to meet us. Thus the "gegen" (against) in Gegenstand. But not just anything at all that happens to strike us (any passing visual or auditory sensation, any sensation of pressure or warmth) is already an object. What encounters us must be determined as standing, something which has a stand and is, therefore, constant (beständig)' (p. 137/140).

In this way, Heidegger says, an object in the strict sense of Kant is neither what is only sensed nor what is perceived (p. 137/140). 'What encounters us in sensation and perception and is intuitively given (anschaulich Gegebene) - the sun and sunshine, rock and warmth - this 'against' (gegen) only comes to the position of a state of affairs standing in itself when the given has already been represented universally and thought in such concepts as cause and effect, i.e., under the principle of causality in general' (p. 139/141). Heidegger thinks that '...when Kant stresses repeatedly: Through the intuition the object is given, through the concept the object is thought, the misunderstanding easily suggests itself that the given is already the object, or that the object is an object only through the concept' (p. 141/143). Both are equally wrong, he claims, since 'the object stands only when the intuition is thought conceptually, and the object only confronts us if the concept designates something intuitively given' (p. 141/143). Therefore, Heidegger suggests that Kant uses the term 'object' in two senses:

18 Every time that the term 'object' appears in what follows it corresponds to the German term Gegenstand, not Objekt. However, I think it is relevant to notice that a reading of the German text of WT shows that in this work Heidegger uses the terms Gegenstand and Objekt interchangeably. This is in opposition to what the translators of PIK and KPM say about Heidegger's use of these two terms in these works. In the Translators' Forward to $P I K$, the translators note that in this work Heidegger 'is careful to maintain' the significant difference between the two German words Gegenstand and Objekt in Kant's usage (1997a, p. xviii). For Kant, 'Gegenstand is the object of thinking as subjective representation. Objekt, on the other hand, is subject to the unity of transcendental apperception, by which the manifold of intuition becomes unified. Gegenstand says what is happening phenomenologically and is phenomenological enactment. Objekt is an experience within subjectivity' (1997a, pp. xviii-xix). Along similar lines, in the Translator's Notes to Part One of KPM, Richard Taft says that 'Kant makes an important distinction between Gegenstand and Objekt, which Heidegger preserves, and which is almost impossible to carry over into English. For Kant, a Gegenstand is a thing in space and time that is encounterable by the senses, while Objekt is an object of thought. Space and Time are themselves Objekt... Heidegger makes a great deal of this word play at various points throughout the book...' (1997b, p. 224). If the translators of PIK and KPM are right about this, it would be interesting to figure out why Heidegger uses the terms Gegenstand and Objekt interchangeably in WT. 
a) A narrow and proper sense: the object is only what is represented in experience (Erfahrung) as experienced (Erfahrenes) (p. 141/144).

b) A wider and improper sense: the object is every thing to which a representation as such refers, be it intuition or thought. In this sense, the object is both: what we have merely thought as such and what is only given in perception (Wahrnehmen) and sensation (Empfinden) (p. 141/144).

Heidegger thinks that although in every case Kant is sure of what he means by 'object', there is in this fluent usage an indication that Kant has 'broached and decided the question of human knowledge and its truth only in a certain respect. Kant has disregarded what is manifest (das Offenbare). He does not inquire into and determine in its own essence that which encounters us prior to an objectification (Vergegenständlichung) into an object of experience (Erfahrungsgegenstand)' (p. 141/144). Insofar as Kant must apparently return to the domain of 'what is manifest', as in the distinction of mere perception (blossen Wahrnehmung) from experience (Erfahrung), Heidegger says, the comparison between the two always takes as its starting point experience, in the light of which perception is seen as a 'not yet' (p. 141/144). Based on this, Heidegger suggests that Kant does not give an account of the improper use of this term when it makes reference to 'what is only given in perception and sensation;' that is, what is 'intuitively given'. ${ }^{19}$

19 With respect to the question that I raised in footnote 16, it is clear that, on the one hand, Heidegger does not think that intuitions give us objects in Kant's narrow and proper use of this term. For Heidegger, as for those who hold a conceptualist reading of Kant's $C P R$, conceptualization is required for objects to appear. Thus, in his explanation of the first principle of pure understanding, i.e., 'The Axioms of Intuition', Heidegger affirms that '[t]he transcendental aesthetic gives us only a preliminary view. Its real thematic reaches its goal only in the treatment of the first principle' (1967, p. 201/204). Even so, it is crucial for Heidegger to highlight that intuition does not lose its decisive role, which is why he adds that 'the object only confronts us if the concept designates something intuitively given'. In light of this, it is clear that Heidegger's view of the decisive role of intuition in Kant's CPR is not based on his conceiving of Kant's account of intuition as giving us objects in what he thinks of as Kant's proper use of the term Gegenstand. Still, Heidegger's reference to a wider and improper use of the term Gegenstand in Kant's texts does point to an object that is 'only given in perception and sensation'. Does this understanding of an object correspond to that which some non-conceptualist readings understand as a result of intuition alone? If the answer is yes, Heidegger would address the conceptualist/non-conceptualist debate regarding Kant's ideas about the being-given of objects by saying that intuitions give us objects in a wider and improper sense, whereas concepts, when they designate something intuitively given (precisely an object in a wider and improper sense), constitute objects in the Kantian narrow and proper use of this term. Furthermore, it is precisely the object in its improper use of the term that Heidegger believes Kant did not think through. In my opinion, Heidegger's analysis in WT does not offer enough evidence to decide whether Kant's wider and improper use of the term Gegenstand corresponds to an object given by intuition alone. This is a relevant issue since, as I have already pointed out, in WT Heidegger is searching for the philosophical foundation of our everyday experience in the world, and the object in Kant's wider and improper use of the term Gegenstand seems to be an appropriate candidate to be part of this type of experience. Thus, figuring out if Heidegger thinks that an object in Kant's wider and improper use of this term corresponds to an object given by intuition alone, could be very helpful for achieving a proper insight into the way in which Heidegger proposes that we understand the philosophical foundation of our everyday experience. If I am right - and following what I already suggested in footnote 16 - then it seems sensible to say that a dialogue between 
In line with the narrow and proper use of the term 'object', that is, what Heidegger calls 'an object in the strict sense of Kant', Heidegger highlights the fact that the object of experience for Kant is nature, but nature understood in the sense of Newton's Principia as systema mundi (p. 126/128). Insofar as Kant defines the thing as a natural thing, Heidegger says, 'we can judge that from the beginning Kant does not pose the question of the thingness of the things that surround us (der uns umgebenden Dinge). This question has no weight for him. His view immediately fixes itself on the thing as an object of mathematicalphysical science' (p. 128/131). Heidegger is very clear in considering this an essential omission:

One could pay homage to the opinion that skipping over the things that surround us and the interpretation of their thingness is an omission for which we can easily make up and which can be fitted onto the definition of natural things, or perhaps could also be pre-arranged. But this is impossible because the definition of the things and the way it is set up include fundamental presuppositions which extend over the whole of being and to the meaning of being in general (Heidegger, 1967, p. 129/131).

This quote shows that Kant's lack of consideration for 'the things that surround us' is central to Heidegger's criticism to his thinking. For Heidegger, the philosophical presuppositions that underlie this omission extend to beings as a whole. Throughout his analysis, Heidegger refers to the realm of things that Kant neglects with expressions such as 'the usual everyday given', or 'that sphere in which we know ourselves immediately at home'.

In what follows I will argue that Heidegger's interpretation of Kant's thought as both delimiting the mathematical, and remaining within the mathematical, causes a tension that is at the heart of his appropriation of Kant's synthetic a priori in $W T$.

\section{Heidegger's omission of 'necessity' and 'universality' from Kant's synthetic a priori}

In her essay Heidegger and the Synthetic A Priori (2007), Cristina Lafont evaluates the extent to which Heidegger adopts Kant's notion of the synthetic a priori. For her, knowing this is crucial for achieving a proper understanding of the relationship between these two thinkers and thus, between Heidegger and transcendental philosophy (p. 104). Lafont thinks that as a consequence of 
Heidegger's interpretation of the ontological difference, Kant's transcendental idealism is transformed into a hermeneutic idealism:

...Heidegger's radicalization of transcendental philosophy aims to show, among other things, that what Kant erroneously thought were the invariant features of any human experience whatsoever (i.e., the pure forms of intuition and the categories) are just a special case of what is in fact a much broader phenomenon, namely, the necessarily circular (i.e., temporal) structure of all human understanding. In this sense, Heidegger welcomes Kant's discovery of the synthetic a priori that is at the core of his Copernican revolution, but he thinks that the special function and status of the synthetic a priori is not an issue that concerns some specific judgements (at the basis of positive sciences) but one that concerns being in general (Lafont, 2007, p. 105).

In light of this, Lafont suggests that an analysis of Heidegger's hermeneutic transformation of the synthetic a priori seems crucial to determining the precise nature of Heidegger's Kantianism (p. 105). Her analysis of this transformation concludes that Heidegger relativizes the notion of truth involved in Kant's notion of the synthetic a priori. The main idea that allows Lafont to reach this conclusion is that Heidegger's understanding in $B T$ of our disclosedness as "essentially factical but true" makes it impossible for Heidegger's notion of the a priori to preserve the features of universality and necessity that this notion has in Kant (pp. 105-113). In her analysis, Lafont points out that:

\begin{abstract}
Although the priority of an understanding of being over and above any experience of entities is, according to Heidegger, a general feature of all human understanding, the paradigm example that Heidegger favors in order to show the plausibility of this hermeneutic idealism is scientific knowledge. For scientific theories, as opposed to most ordinary understanding, are explicit and highly articulated kinds of interpretation, which for this reason allow for closer scrutiny as to their origin, structure, relationship to experience and so on. Still, as a kind of interpretation they are subject to the same circular (and thus projective) conditions of understanding (Lafont, 2007, p. 109).
\end{abstract}

With this in view, Lafont refers to $W T$ as a work in which Heidegger offers a very detailed explanation of the structure and characteristics of such a projection through an analysis of the transformation of science from the ancient conception of nature into modern natural science. Lafont points out that Heidegger interprets this transformation as a change of "metaphysical projection" or, as it is called these days, a paradigm shift (p. 109):

Heidegger makes clear that the core of this paradigm shift does not consist in the emphasis on observation or experimentation, but on the projection of an entirely different understanding of the being of entities, a new world-disclosure brought about through the establishment and definition of new basic concepts by modern scientists such as Galileo and Newton. According to Heidegger, to the extent that these new concepts organize all possible experience in advance, the grounding postulates or axioms of 
these modern theories through which these concepts are defined have the status of synthetic a priori knowledge. For only on the basis of such postulates and axioms is something like empirical knowledge possible at all (Lafont, 2007, pp. 109-110).

I agree with Lafont that for Heidegger both Galileo and Newton carry out a transformation of the projection of the being of entities that brings with it a new world disclosure, but I think that she is wrong in saying that Heidegger thinks of Galileo and Newton as representatives of Kant's synthetic a priori. In fact, when Lafont suggests this idea, she is commenting on a section of WT entitled 'Synthetic Judgments A Priori Necessarily Lie at the Basis of All Knowledge' (1967, pp. 179-181/183-184). In this section Heidegger mentions neither Galileo nor Newton as examples of scientists that placed synthetic a priori knowledge at the basis of their scientific project. One could say that this omission is irrelevant and that, insofar as Heidegger refers to science, Galileo and Newton must be considered as representatives of synthetic a priori knowledge. However, I do not think this is the case, at least not if one examines Heidegger's own understanding of the synthetic a priori.

Like Lafont, Glazebrook thinks that Heidegger neglects the epistemic certainty that is definitive for Kant of a priori judgements, arguing that Heidegger conflates the pure and the a priori in his reading of Kant (2000, p. 49). This conflation is for her the result of Heidegger's interest in understanding 'how being is a priori but hardly pure, since it must for Heidegger belong to beings. He attempts therefore to retrieve the a priori from pure reason, and in doing so he fails to see the definitive characteristic of the a priori for Kant' (p. 50). Nevertheless, unlike Lafont, Glazebrook recognizes that Heidegger does not use the expression 'synthetic a priori' in reference to Newton, rightly noticing that:

When Heidegger wishes in Die Frage nach dem Ding to pursue the question of what is already given and therefore certain in any knowledge, he does not do so on the basis of Kant's a priori. Rather he turns to the Greeks and the mathematical, despite the fact that Kant is the subject of the course and that the Kantian a priori is the obvious candidate for such a discussion. Heidegger intends the mathematical to do exactly the job Kant assigned to the a priori. As the a priori carried the epistemic force of certainty for Kant, so the mathematical entails the certainty of givenness in Heidegger's analysis (Glazebrook, 2000, p. 50).

Glazebrook's observations imply that the reason why Heidegger does not mention Galileo or Newton as examples of synthetic a priori knowledge in the above-mentioned section of $W T$, or why in this work Heidegger never uses the expression 'synthetic a priori' in relation to Newton, preferring the term 
'the mathematical', is that he does not want to attach the notions of necessity and universality (epistemic certainty) to Kant's synthetic a priori. Thus, what Lafont takes to be the cause of Heidegger's failure to transform Kant's a priori, is something that Heidegger deems necessary. Why is this so?

\section{Kant's thought as accounting for the possibility of reality's becoming an object 'for us': Heidegger's basis for ascribing the notion of synthetic a priori to Kant but not to Newton}

In WT Heidegger makes two statements that can shed light on how he understands Newton and Kant. The first corresponds to his views on Kant's understanding of space and time, and the second to Kant's understanding of the anticipations of perception. I will present both, and then offer my analysis.

With respect to space and time as forms of pure intuition, Heidegger affirms the following:

Space, according to Kant, is neither a thing that is itself present at hand (an sich vorhandenes Ding) (Newton), nor a manifold of relationships which result from the relations of things that are themselves present at hand (an sich vorhandene Dinge) (Leibniz). Space is the single whole of beside one another, behind and over one another, which is immediately represented in advance in our receiving what encounters. Space is only the form of all appearances of the outer senses; i.e., a way in which we take in what encounters us. It is thus a determination of our sensibility (Heidegger, 1967, p. 199/202).

Heidegger emphasises the fact that Kant's understanding of space - unlike Newton's - only makes sense from the subjective condition, which he reads in the following passage he quotes from Kant's $C P R$ : 'It is, therefore, solely from the human standpoint that we can speak of space, of extended things, etc. If we depart from the subjective condition under which alone we can have outer intuition...the representation of space stands for nothing whatsoever' (Kant in Heidegger, 1967, p. 199/202). ${ }^{20}$ Heidegger thinks that these ideas hold good for Kant's understanding of time (p. 199/202). As Sebastian Gardner notes, both Newton and Leibniz 'maintain that space and time are contained in the world independently of the subject's awareness, and that we have representations of space and time because we have knowledge of reality. That is what Kant denies' (1999, p. 88). Whereas for Newton, space and time are 'real existences' (p. 88), for Kant space and time are not real in an absolute sense (p. 71). 
With respect to the anticipations of perception, specifically in reference to what Heidegger thinks is strange about the anticipations, he says:

And what can be stranger than this, that even where we are dealing with such things as sensations, which assail us, which we only receive, that just in this "toward us" (auf uns $z u$ ) a reaching out and an anticipation by us is possible and necessary? At first glance, perception as pure reception and anticipation as a reaching and grasping beforehand (entgegen-fassendes Vorgreifen) are thoroughly contradictory. And yet it is only in the light of the reaching and anticipating presentation of reality ${ }^{21}$ that sensation becomes a receivable, encountering this and that' (Heidegger, 1967, p. 220/222).

Heidegger thinks that 'Kant's discovery of the anticipations of the real in perception is especially astonishing if one considers that, on the one hand, his esteem of Newtonian physics and, on the other, his fundamental position in Descartes' concept of the subject are not suited to promote the free view of this unusual anticipation in the receptivity of perception' (1967, p. 222/224). For Heidegger, insofar as modern science interprets the given of sensations (colour, sounds, pressure, impact) as the primary building blocks out of which a thing is put together, it interprets the fragment-things, the sensations, as effects of a cause. For example, physics establishes that the cause of colour is light waves. For Heidegger, the domain of the givenness of sensations and what is to be explained, i.e., colour as given, have been simultaneously abandoned in this explanation of sensation. In this way, he says, sensations are represented as something in themselves: they are themselves made into things (pp. 208-209/211). Thus, Heidegger argues, the mathematical starting point concerning the thing as something extended and movable in space and time leads to the consequence that the usual everyday given (das umgänglich alltäglich Gegebene) is apprehended as mere material and is fragmented into the manifoldness of sensations. The mathematical starting point 'first brought about that keen ear' (hellhörig) for a corresponding theory of sensation (2018, p. 145/214). Although Kant remains at the level of this starting point (in which Heidegger clearly thinks Newton also remains) and has therefore, says Heidegger, skipped the realm in which we know ourselves immediately at home, his metaphysical interpretation of the givenness of sensations differs from all interpretations before and after him, and it is superior to all of them (1967, p. 211/214). Sensation is not for Kant a thing for which causes are sought, but a given whose givenness is to be understood through the study of 
the conditions of the possibility of experience (p. 217/219). It is this view that allows Kant to discover the anticipations in the receptivity of perception.

These two statements show that Heidegger is interested in demonstrating that for Kant, unlike Newton, we cannot understand 'things' as independent from our mode of cognition. As Gardner explains, '[p]re-Copernican philosophical systems, according to Kant, set out by assuming a domain of objects which are conceived as having being, and a constitution of their own - a class of real things. In this sense, previous philosophical systems are all realist. (This generalisation includes, strange though it may sound, idealism of George Berkeley's sort, because the 'real things' in question may be mental)' (1999, p. 38). With this idea in mind, Gardner affirms that in contrast to Kant's doctrine of transcendental idealism, '[a]1l other philosophical positions are united in supposing that the objects of our cognition are transcendentally real, i.e., that they have the constitution which we represent them as having independently of (without being determined to do so by) our mode of cognition, and so that things can in principle be known as they are in themselves. Kant calls this claim transcendental realism' (p. 95). As Gardner shows, Kant's transcendental idealism is fundamentally connected to his preoccupation with accounting for the possibility of reality's becoming an object for us (pp. 27-50). Kant's transcendental idealism is concerned with the question 'what makes reality into an object for us?' (p. 34). On Kant's view, Gardner claims, all the epistemologies of pre-Kantian philosophy 'reduce on examination to the bare, non-explanatory claim that we represent real things because they affect us and because we have an immanent capacity to represent them' (p. 35).

I suggest that this is the key to understanding why Heidegger ascribes the synthetic a priori to Kant but not to Newton. For Kant, what a 'thing' is, is not independent from our mode of cognition, which means that he addresses the question regarding what a thing is for us. In contrast, Heidegger thinks that, for Newton, things can be known as they are in themselves. Heidegger therefore ascribes the notions of universality and necessity (epistemic certainty) to the mathematical and thus to Newton: from Newton's perspective (that of modern science), we can conceive of the acquisition of absolutely certain knowledge of things because we can know, in principle, how things are in themselves; i.e., things are not dependent on our subjective condition. Nevertheless, Kant did think that his notion of the a priori entails the possibility of acquiring absolutely certain knowledge of things. Kant thought of space and time (in combination with the pure concepts of the understanding) as providing a criterion for truth and thus as universal and necessary. Heidegger would certainly have been aware of this. Thus one may ask: what is Heidegger's aiming at when drawing 
attention to the distinction between Kant and Newton in this respect? Based on my analysis so far, I suggest that Heidegger draws attention to the distinction between Kant and Newton with respect to the epistemic certainty in their a priori, in order to show that even though Kant does not give attention to that which encounters us prior to an objectification into an object of scientific experience, his focus on intuition betrays the possibility of doing it. As it will become clear in what follows, this is crucial for understanding Heidegger's appropriation of Kant's synthetic a priori in relation to transcendence.

\section{The synthetic a priori and transcendence as 'the between' (das Zwischen) us and things}

Heidegger thinks that Kant's new definition of knowledge results in judgement being understood in its 'relation to the object' and, thus, to intuition (pp. 157, 170/160, 173-174), unlike the traditional definition of judgement as merely the connection of representations (pp. 154-157/158-160). The 'relation to the object' now defines both analytic and synthetic judgements, although the nature of this relation is different in each case (pp. 162-164/165168). For Heidegger, the idea of a 'relation' to the object embodies the notion of transcendence in Kant's thought: transcendental reflection, Heidegger says, 'is not directed upon objects themselves nor upon thought as the mere representation of the subject-predicate relationship, but upon the passing over and the relation to the object as this relation' (p. 176/179).

According to Barton, Heidegger's interpretation of Kant's focus on intuition in WT turns out to be an appreciation of Kant's notion of transcendence (1973, p. 17). In Heidegger's words: 'When, in this lecture, we constantly ask about the thingness of the thing and endeavour to pace ourselves into the realm of this question, it is nothing else than the exercise of this transcendent viewpoint and mode of questioning' (1967, p. 179/182-183). As Barton explains, transcendence 'is what the Critique of Pure Reason opens for us, in order that knowledge of objects can become possible for us. Thus, the transcendence of human knowledge is revealed through the analysis of the principles of pure understanding as grounded in intuition, which transcendence makes experience itself possible' (1973, p. 17).

In $W T$, Heidegger considers the 'System of All Principles of Pure Understanding' to be the ground-providing centre of the CPR (1967, pp. 121124/124-126). These principles are the 'principles of pure reason upon whose ground something like a thing in its thingness is determined' (p. 122/124). As expected, Heidegger is clear in saying that these four principles are synthetic 
a priori judgements. He thus treats them with great attention and offers an analysis of each of their proofs. Throughout this analysis, Heidegger highlights the inherent circularity implied in each of the proofs, and warns the reader 'not only to suspect the circle and so to create doubts about the cleanness of the proof, but to recognize the circle and to carry it out as such' (p. 224/226). He thinks that this circularity constitutes the essence of experience (pp. 241242/243-244). 'Experience is in itself a circular happening through which what lies within the circle becomes exposed. This open, however, is nothing other than the between (Zwischen) - between us and the thing' (p. 242/244). This is why Barton rightly affirms that in WT transcendence is the "between" (1973, p. 17).

Heidegger thinks that this circularity finds its clearest expression in the highest principle of all synthetic a priori judgements: 'The conditions of the possibility of experience in general are likewise conditions of the possibility of the objects of experience. Whoever understands this principle understands Kant's Critique of Pure Reason... But we have to bring this by an appropriate transformation to fulfilment in the future' (p. 183/186).

Based on my analysis, I think that this appropriation consists in making all the necessary changes to the synthetic a priori so that it can account for that which is given in ordinary experience. As I have already suggested, Heidegger thinks that these changes to the synthetic a priori are justified given Kant's focus on intuition; intuition, ultimately, can work as a point of access to the things that surround us.

Along these lines, I think Heidegger's refusal to attach epistemic certainty to Kant's a priori in WT is based on his interest in showing that this notion can open up the relation between the human being and things, that is, transcendence. Heidegger thinks that if he assigns epistemic certainty to Kant's a priori, his thought remains within the understanding of the thing as an object of mathematical-physical science and, in this way, it does not open up transcendence in full but restricts our relation to one way of disclosing reality; that is, as a scientifically-determined reality.

Therefore, Heidegger's view that Kant's focus on intuition is a delimitation of the mathematical means that he thinks that Kant's notion of the synthetic a priori involves the possibility of treating it as co-extensive with the realm of ordinary or everyday experience. Thus, Heidegger adapts Kant's notion of the synthetic a priori to his own ideas on being: the a priori pertains to beings - is not taken out of pure reason alone - without being experientially derived and, in this way, Kant's synthetic a priori opens up transcendence as the 'between us and things'. 
I will end this paper by making a few remarks on the importance of reading Heidegger's interpretation of Kant's thought in WT in light of the possibilities that it opens up within the history of metaphysics.

Following my analysis in this paper, I suggest that Lafont's view of Heidegger's failure to adopt Kant's synthetic a priori loses its relevance. As I have argued, in $W T$ Heidegger thinks that what takes place in the scientific disclosure of the world is just one - limited - way of viewing things, and he thinks that the mathematical - the "synthetic a priori" that is the basis of scientific knowledge -, carries the epistemic certainty characteristic of Kant's a priori. Thus, Heidegger would agree with Lafont in that the 'scientific a priori' entails universality and necessity, thereby jettisoning the central point of her criticism.

I suggest that the fact that in WT Heidegger assigns to the mathematical the job Kant assigned to the a priori is of crucial importance for understanding Heidegger's appropriation of Kant's synthetic a priori in this work. This being the case, it seems reasonable to say that further work needs to be done in order to clarify the continuities and discontinuities between Heidegger's appropriation of Kant's a priori in his early and later works. In the case of the former, there is general agreement that Heidegger understands Kant's synthetic a priori in ontological terms and that his ontological project would not accept the objection that there are exceptions (or contingencies related) to the "rule" that the totality of being opens itself to the existential modes described in his existential analytics and in his project of a fundamental ontology (Verstehen, Auslegung, Befindlichkeit, etc.). Thus, it becomes relevant to evaluate if Heidegger's refusal to attach universality and necessity to the synthetic a priori in the mid-30s challenges his earlier appropriation of this notion and, if it does, in what way and to what extent. In the case of the latter, my analysis has shown that in WT Heidegger wants to take Kant's synthetic a priori to a wider dimension of our experience in the world, a dimension where he thinks that epistemic certainty has no place, that is, our ordinary experience of things. He is in search of the philosophical foundation of the superior truth involved in everyday experience, and he thinks that Kant's synthetic a priori encloses the possibility of helping in this task; a possibility that rests on Heidegger's interpretation of Kant's focus on intuition. Thus, Heidegger's interpretation of Kant's thought in WT must be read under the light of this possibility.

As I have argued elsewhere, Heidegger's analysis of representation in $W T$ - for which his distinction between intuitive representations and representations against ordinary experience is decisive - shows that in the mid-30s Heidegger realizes that thinking being as the a priori carries a danger, which consists in the 
fact that being can dissociate from that which is given in ordinary experience and become determined by pure reason alone. I argued that this danger is the decisive factor underlying his critical stance towards modern representations in the mid-30s, and that in view of this danger, Heidegger is compelled to find a way of thinking the a priori so that it cannot detach itself from ordinary experience (2019). Based on the analysis that I have offered in this paper, I suggest that Heidegger's appropriation of Kant's synthetic a priori in WT is in line with this search.

Therefore, Heidegger's interpretation of intuition in WT stands as an important account of a phenomenological understanding of the human being. As Barton rightly notes, Heidegger's interest in transcendence in $W T$ does not mean a loss of interest in man (1973, p. 17). On the contrary, Heidegger explicitly says in the final paragraph of $W T$ that:

Kant's questioning about the thing asks about intuition and thought, about experience and its principles, i.e., it asks about man. The question "What is a thing?" is the question "Who is man?" That does not mean that things become a human product (Gemächte) but, on the contrary, it means that man is to be understood as he who always already leaps beyond (überspringt) things, but in such a way that this leapingbeyond is possible only while things encounter (begegnen) and so precisely remain themselves (sie selbst bleiben) - while they send us back behind ourselves and our surface' (Heidegger, 1967, p. 244/246).

This quote clearly suggests that we can achieve a proper understanding of the human being only from the perspective of his encounter with things, in which these are allowed to remain themselves. As my analysis has shown, Heidegger thinks that this type of encounter takes place in everyday experience, which explains why he thinks that the truth involved in this type of experience is 'superior', and justifies the need for seeking a philosophical foundation for it. It has also become clear that Heidegger considers intuition to be of crucial importance in this search. ${ }^{22}$

\section{References}

ALLAIS, L. "Manifest Reality: Kant's Idealism \& his Realism". New York, NY: Oxford University Press, 2015.

BARTON Jr, W.B. 'An Introduction to Heidegger's What is a Thing?'. Southern Journal of Philosophy, Vol. 11, 1, 2, 1973, pp. 15-25. 
BLATTNER, W. 'Heidegger's Kantian idealism revisited'. Inquiry: An Interdisciplinary Journal of Philosophy, 47:4, 2004, pp. 321-337.

CARR, D. "Heidegger on Kant and Transcendence". In: Crowell, S. \& Malpas, J. (eds.). Transcendental Heidegger. New York, NY: Stanford University Press, 2007. pp. 28-42. CRICHTON, C. "Heidegger on representation: the danger lurking in the a priori". Tópicos, Revista de Filosofía, 56, enero-junio, 2019, pp. 167-195.

CROWELL, S., MALPAS, J. "Introduction”. In: Crowell, S., Malpas, J. (eds.). Transcendental Heidegger. New York, NY: Stanford University Press, 2007. pp. 1-9. DAHLSTROM, D. "Heidegger's Kantian Turn: Notes to His Commentary on the 'Kritik Der Reinen Vernunft"”. Review of Metaphysics, 45:2, 1991, pp. 329-361.

. "Heidegger's Transcendentalism". Research in Phenomenology, 35:1, 2005, pp. 29-54.

. "Transcendental Truth and the Truth That Prevails". In: Crowell, S., Malpas, J. (eds.). Transcendental Heidegger. New York, NY: Stanford University Press, 2007. pp. 63-73.

GARDNER, S. "Kant and the Critique of Pure Reason". London UK: Routledge, 1999. GLAZEBROOK, T. "Heidegger's Philosophy of Science". New York, NY: Fordham University Press, 2000.

GOLOB, S. 'Heidegger on Kant, Time and the 'Form' of Intentionality”. British Journal for the History of Philosophy, DOI: 10.1080/09608788.2012.692662, 2012.

HEIDEGGER, M. (1927/28). "Phenomenological Interpretation of Kant's Critique of Pure Reason." Translated by Parvis Emad and Kenneth Maly, Bloomington, IN: Indiana University Press, 1997a.

. (1927/28). "Phänomenologische interpretation von Kants Kritik der Reinen Vernunft." Published by Ingtraud Görland, Frankfurt am Main: Vittorio Klostermann GmbH, 1995.

. (1927). "Being and Time". Translated by John Macquarrie and Edward Robinson, Oxford: Blackwell Publishing, 2011.

. (1927). "Sein und Zeit". Published by Friedrich-Wilhelm von Herrmann, Frankfurt am Main: Vittorio Klostermann GmbH, 1977.

. (1929). "Kant and the Problem of Metaphysics". Translated by Richard Taft, Bloomington, IN: Indiana University Press, 1997b.

. (1929). "Kant und das Problem der Metaphysik". Published by FriedrichWilhelm von Herrmann, Frankfurt am Main: Vittorio Klostermann GmbH, 1991.

. (1935/36). "What is a thing?". Translated by W. B. Barton and V. Deutsch, South Bend, IN: Gateway Editions, 1967.

. (1935/36). "The Question Concerning the Thing. On Kant's Doctrine of the Transcendental Principles". Translated by J. D. Reid and B. D. Crowe, London-New York: Rowman \& Littlefield International, 2018.

. (1935/36). "Die Frage nach dem Ding. Zu Kants Lehre von den transzendentalen Grundsätzen." Published by Petra Jaeger, Frankfurt am Main: Vittorio Klostermann $\mathrm{GmbH}, 1984$. 
. (1961). "Kant's Thesis about Being". In: Pathmarks. Translated by Ted E. Klein Jr. and William E. Pohl, Cambridge: Cambridge University Press, 1998. . (1961). "Kants These über das Sein". In: Wegmarken. Published by FriedrichWilhelm von Herrmann, Frankfurt am Main: Vittorio Klostermann GmbH, 1976. KANT, I. (1781/1787). “Critique of Pure Reason”. Translated and edited by Paul Guyer and Allen Wood, Cambridge: Cambridge University Press, 1998.

LAFONT, C. "Heidegger and the Synthetic A Priori". In: Crowell, S. \& Malpas, J. (eds.). Transcendental Heidegger. New York, NY: Stanford University Press, 2007, pp. 104-118.

MCLEAR, C. "The Kantian (Non)-conceptualism Debate". Philosophy Compass, 9:11, pp. 769-790, 10.1111/phc3.12166, 2014. 